\title{
DIALOG MIĘDZY CYWILIZACJAMI
}

Marta Kosmala

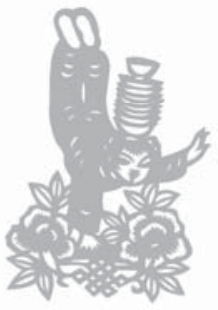

\section{DWIE CYWILIZACJE - DWA SYSTEMY WARTOŚCI DWIE WIZJE PRAW CZŁOWIEKA}

\section{Wprowadzenie}

Praca ta jest próbą odpowiedzi na pytanie, czy dwie odmienne cywilizacje wraz z ich specyficznymi systemami wartości mogą się wzajemnie zrozumieć, a nawet okazać komplementarne w imię stworzenia uniwersalnego systemu ogólnoludzkich praw i obowiązków. Kontrastując założenia, idee i koncepcje kultury Zachodu oraz Azji Wschodniej przedstawię podstawowe różnice w porządkowaniu oraz interpretacji fundamentalnych wartości w obrębie dwóch wielkich kręgów kulturowych. Postaram się także wskazać zbieżności z pozoru sprzecznych systemów wartości, by rozważyć możliwość stworzenia nowej etyki globalnej czerpiącej z najlepszych tradycji obydwu cywilizacji.

\section{Dwa odmienne systemy wartości ${ }^{1}$}

\section{A. Równouprawnienie a wszechobecna hierarchia}

Społeczeństwa Zachodu oraz Azji Wschodniej różni typ struktury organizacyjnej. Pierwsze zorganizowane są „poziomo” i opierają się na założeniu równości ludzi oraz stosunkach partnerskich pomiędzy jednostkami. Drugie zaś charakteryzuje konstrukcja ,pionowa”, czyli hierarchiczny porządek społeczny oparty na sto-

${ }^{1}$ Systematyka inspirowana tekstem Krzysztofa Gawlikowskiego, Dwie cywilizacje $i$ ich wizje człowieka: Zachód i Azja Wschodnia, ISP PAN, Warszawa 1997, s. 8-20. 
sunku „wyższy” - „niższy” rangą. Status jednostki określany jest przez jej miejsce wewnątrz grupy oraz pozycję danej grupy w społeczeństwie. Jednostka winna jest szacunek i posłuszeństwo osobom zajmującym wyższą od niej pozycję. Natomiast jednostki o randze nadrzędnej pełnią funkcję kierowniczą i opiekuńczą. Liderzy muszą mieć stałe poparcie podwładnych i nie mogą niczego narzucać arbitralnie, ponieważ najwyższym ideałem jest utrzymanie harmonii oraz dobro grupy.

Zasada harmonijnego istnienia i współdziałania w społeczeństwie zorganizowanym „pionowo” ma swe odzwierciedlenie również w relacjach człowieka z naturą. Podczas gdy zgodnie z tradycją judeochrześcijańską istota ludzka ma poskramiać i podporządkowywać sobie naturę, konfucjanizm wyklucza możliwość „podbijania jej” czy „,czynienia sobie posłuszną".

Hierarchizacja relacji międzyludzkich z różnym natężeniem występuje na wszystkich obszarach cywilizacji konfucjańskiej. Szczególnie silnie zakorzeniła się w społeczeństwie japońskim. „Każdą próbę zrozumienia Japończyków należy zacząć od wyjaśnienia, co znaczy dla nich zająć właściwe miejsce. Zaufanie, jakie pokładają w hierarchii i porządku oraz wiara [człowieka Zachodu - przyp. MK] w wolność i równość to dwa przeciwstawne bieguny (...). Przeświadczenie o wartości [hierarchii - przyp. MK] jest podstawą japońskiego pojmowania stosunku człowieka do drugiego człowieka (...) Japończycy posługują się więc, podobnie jak wiele ludów Pacyfiku, tzw. językiem szacunku, któremu towarzyszą odpowiednie ukłony głową lub całym ciałem. Zachowanie to określają szczegółowe zasady i reguły. Nie wystarczy wiedzieć komu należy się kłaniać, ale trzeba jeszcze wiedzieć jak i ile razy (...) Właściwe zachowanie powinno uwzględnić nie tylko różnice klasowe, ale również płeć, wiek powiązania rodzinne oraz dotychczasowe stosunki”'2.

W przypadku społeczeństw „zorganizowanych pionowo” zupełnie inaczej niż na Zachodzie kształtuje się życie społeczne i polityczne. Nie pozostaje to bez wpływu na model liberalnej demokracji, która na gruncie zhierarchizowanej struktury społecznej, nie uwzględniającej ani równych praw obywateli, ani autonomii jednostek oraz równowagi władz, przybiera postać specyficznej dla tej części świata formy „przyjaznego autorytaryzmu”. System ten opiera się na współdziałaniu niewielkich grup ludzkich, których podstawą jest utrzymanie wzajemnej kontroli, jak najlepszym przestrzeganiu obowiązujących przepisów oraz powstrzymywaniu zachowań wybiegających poza przyjętą normę. Władza jest tu wszechobecna i reguluje wszelkie sfery życia obywateli, posługując się , przyjaznym dla jednostki” systemem nagród. Szacunek oraz zaufanie dla zwierzchników są kształtowane tak, by okazywać je spontanicznie i dobrowolnie. Dopiero w przypadku, gdy łagodniejsze środki perswazji zawiodą, państwo używa środków przymusu. Mimo formalnego przyswojenia norm i instytucji demokratycznych w systemach ,przy-

\footnotetext{
${ }^{2}$ Ruth Benedict, Chryzantema i miecz. Wzory kultury japońskiej, PIW, Warszawa 1999, s. 50, 54.
} 
jaznego autorytaryzmu" przestrzegane są raczej zbiorowe prawa kolektywów, niż indywidualne swobody jednostek. „(...) Nie możemy pozwolić, by indywidualne prawa zdestabilizowały kraj (...), w zrównoważonym stosowaniu praw człowieka powinniśmy brać pod uwagę nasze wartości (...)" - napisały we wspólnym oświadczeniu rządy Chin i Malezji ${ }^{3}$.

Zwolennicy „przyjaznego autorytaryzmu” przekonują, że w państwach należących do cywilizacji konfucjańskiej nieunikniona jest transformacja importowanej z Zachodu liberalnej demokracji do modelu „demokracji w stylu azjatyckim”, ponieważ silna pozycja rządu oraz wszechobecna hierarchia są w przypadku azjatyckich systemów społeczno - politycznych „naturalne i dobre”4. Lee Kuan Yew, były premier Singapuru, twierdzi nawet, że ,wartości azjatyckie są nadrzędne w stosunku do wartości zachodnich, ponieważ mogą uchronić Azję przed problemami stagnacji ekonomicznej, nieefektywnością systemu politycznego, brutalną przestępczością oraz zepsuciem moralnym społeczeństwa"5.

W przypadku cywilizacji konfucjańskiej wszechobecna hierarchia ma swe tradycyjne korzenie w społeczeństwie. Charakterystyczny dla ustrojów Azji Wschodniej stosunek ,patron - klient” wypływa ze skomplikowanej sieci społeczno-politycznych powiązań i lojalności. Rząd zapewnia dobra i usługi, zaś obywatele odwdzięczają mu się politycznym i ekonomicznym poparciem ${ }^{6}$. Dla porównania, zachodnie tradycje hierarchiczne, które ostatecznie zniwelowała era kapitalizmu i demokracji liberalnej miały jedynie charakter formalny i dotyczyły głównie instytucji.

\section{B. Porzadek oparty na nakazach bożych a brak idei Boga}

Podczas gdy dla potępienia czynów ludzi cywilizacji Zachodniej właściwe jest pojęcie grzechu, jego odpowiednik na obszarze cywilizacji konfucjańskiej stanowi uczucie wstydu. Rozróżnienie to ma swoje źródło w odmiennej naturze ludzkiej odpowiedzialności. W kulturze opartej na indywidualistycznej koncepcji człowieka, zgodnie z założeniami tradycji judeochrześcijańskiej, mechanizmem kontrolującym zachowania jednostki jest sumienie, dane jej od Boga - Stwórcy. Natomiast w przypadku cywilizacji opartej na kolektywistycznej naturze jednostki w roli sędziego występuje wspólnota społeczna, która określa rozróżnienie między tym, co słuszne, a tym, co naganne. W przypadku człowieka pochodzącego z Azji Wschod-

\footnotetext{
3 "South China Morning Post" z 12 stycznia 1992 r., s. 5, za: Lam Lai Sing: A Short Note on ASEAN-Great Power Interaction, "Contemporary Southeast Asia", marzec 1994.

${ }^{4}$ Steven J. Hood: The Myth of Asian Style Democracy, “Asian Survey”, wrzesien 1998, s. 856.

${ }^{5}$ Ibidem, s. 853.

${ }^{6}$ Lucian W. Pye, Money Politics and Transitions to Democracy in East Asia, "Asian Survey", marzec 1997, s. 213-28.
} 
niej największą karą jest potępienie przez grupę, a w konsekwencji poczucie wstydu i niezwykle trudna do odkupienia utrata twarzy?

Zatem największą przepaść kulturową między cywilizacją Zachodu oraz Azji Wschodniej tworzy brak w tradycji tej drugiej idei Boga. To właśnie Bóg w każdej kulturze opartej na wierze w „monoteistycznego stwórcę” jest punktem wyjścia wszystkich pojęć i koncepcji oraz porządkowania ich w systemy wartości. W przypadku cywilizacji Zachodu są to idee prawa oparte na Piśmie Świętym, Dziesięciorgu Przykazaniach oraz nieśmiertelnej duszy ludzkiej ofiarowanej człowiekowi na jedno, jedyne życie. Na koncepcji odróżniającej człowieka od innych istot żywych - duszy - opiera się przyrodzona i niezbywalna godność jednostki, jej wolna wola oraz zakaz odbierania życia bliźniemu. Nawet w wyniku postępującej na Zachodzie sekularyzacji życia społecznego jego reguły opierają się na koncepcjach prawa naturalnego oraz demokratycznej równości jednostek inspirowanych ideami chrześcijaństwa.

Oparta na filozofii konfucjańskiej wizja świata zdeterminowana jest przez ateistyczną koncepcję wzajemnej współzależności i harmonicznego współistnienia ożywionych i nieożywionych elementów wszechświata jako odwiecznego i samoistnego organizmu. Człowiek wraz ze zwierzętami oraz bóstwami jest jego nieodłączną częścią i musi dostosować się do dynamiki cyklicznych przemian w nim zachodzących. Podczas gdy chrześcijanina dzieli od jego Boga nieprzekraczalna bariera niewiedzy, filozofia buddyjska w japońskiej wersji głosi, że każdy człowiek może stać się Buddą, oraz, że zasady praktykowania cnoty nie zostały spisane w świętych pismach, lecz odnajdują się w głębi ludzkiej duszy, gdy doznaje ona oświecenia. Co więcej, boskość nie oznacza dla Japończyka idei absolutnego dobra. Bogowie Kraju Kwitnącej Wiśni są jednocześnie dobrzy i źli, zaś ulubionym bóstwem japońskiego panteonu jest Susanoo - „Jego Zapalczywa Męska Dostojność", który według mitologii został wygnany z Nieba do Krainy Mroków ${ }^{8}$.

Filozofia konfucjańska uzupełniona o pojęcie reinkarnacji oraz karmy, jak również wywodzącej się z tradycji chińskiej idei przeznaczenia nadaje inne znaczenie życiu jednostki. W wyniku wiary w reinkarnację śmierć nie ma wymiaru ostatecznego, natomiast doktryna karmy thumaczy nieszczęścia spotykające jednostkę winami popełnianymi w poprzednich lub w następnych wcieleniach. Wyjaśnia to obojętność, z jaką otoczenie bardzo często traktuje cierpiących. W tradycji konfucjańskiej funkcjonuje odmienna od chrześcijańskiej idea duszy. Tylko człowiek szlachetny, czyli postępujący w stosunku do drugiego człowieka zgodnie z zasadami humanitarności i samodoskonalenia, żyjący zgodnie z zasadami etykiety (Azjaci kładą nacisk na obowiązki i powinności) jest w stanie wykształcić w sobie peł-

\footnotetext{
${ }^{7}$ Raymond Cohen, Negotiation. The Cultural Roots, "Negotiating Across Cultures" 1997, s. 28 -31 .

${ }^{8}$ Ruth Benedict, Chryzantema i miecz..., s. 179-180.
} 
nowartościową duszę. Koncepcja ta tłumaczy zjawisko głębokiego szacunku dla ludzi posiadających wysokie rangi w hierarchii społecznej (wiekowych i żyjących według wartości konfucjańskich) oraz bagatelizowania wartości życia dzieci oraz dysydentów, którzy nie posiadają ludzkiej duszy, a jedynie jej namiastkę właściwą wszystkim elementom natury ${ }^{9}$.

Chińczycy, podobnie jak chrześcijanie, wyraźnie odróżniają dobro od zła. W oparciu o filozofię Konfucjusza stworzyli „absolutny wzorzec moralny oparty na wyższej zasadzie etycznej jen, która oznacza odpowiednie postępowanie i życzliwość”10. „Taki kodeks moralny nadawał się dla Chińczyków, których niższa natura wymagała sztucznie nakładanych ograniczeń". Autorem tych słów jest XVIII-wieczny shintoista Motoori. Popierają go japońscy filozofowie i myśliciele religijni głosząc, że „kodeks etyczny oparty na walce dobra ze złem jest Japończykom obcy”11. Sir George Sansom napisał w książce pt. „Japan - A Short Cultural History”: „Wydaje się, że na przestrzeni swoich dziejów Japończycy do pewnego stopnia zachowywali tę niezdolność rozróżnienia między dobrem, a złem, lub też niechęć do tego, by się z problemem zła zmierzyć" ${ }^{2}$. Według Japończyka w życiu każdego człowieka zdarzają się chwile, gdy ujawnia się jego ,szlachetna” bądź „grubiańska” dusza. Przeznaczeniem żadnej z nich nie jest ani zbawienie, ani potępienie, lecz obie są niezbędne ${ }^{13}$.

\section{Niezależność społeczna a nadrzędne znaczenie rodziny}

W kulturze Azji Wschodniej nastąpiła nie znana na Zachodzie gloryfikacja rodziny jako podstawowego podmiotu społecznego, autonomicznego wobec państwa a nawet do pewnego stopnia w stosunku do niej nadrzędnego. Podstawową wartością filozofii konfucjańskiej stała się, określająca stosunek do drugiego człowieka, cnota humanitarności (Ren), której podstawę stanowią szacunek dla starszych $(D i)$ oraz „cnota nabożności synowskiej” (Xiao ${ }^{14}$. Złamanie tej ostatniej zasady zaliczane jest do najcięższych zbrodni. Rodzina zaś traktowana jest w tradycji konfucjańskiej jako jeden organizm posiadający wspólną „duszę - moc”15. -314 .

${ }^{9}$ K. Gawlikowski, Zapiski z pawilonu odlatujacego żurawia, „Azja Pacyfik” 2000, t. 3, s. 312

${ }^{10}$ Ruth Benedict, Chryzantema i miecz..., s. 179.

${ }^{11}$ Ibidem.

${ }^{12}$ Cyt. za: Ruth Benedict, Chryzantema i miecz..., s. 178.

${ }^{13}$ Szlachetna lub grubiańska dusza Japończyka powinna ujawniać się w odpowiedniej sytuacji - określonej przez tradycję i normy obyczajowe.

${ }^{14}$ Roman Sławiński, Rola jednostki w społeczeństwie konfucjańskim, w: Uniwersalizm praw człowieka. Idea a rzeczywistość w krajach kultur pozaeuropejskich, Askon, Warszawa 1998, s. 28.

${ }^{15}$ Krzysztof Gawlikowski, Dwie cywilizacje ...,, s. 14. 
Chińskie prawo moralne wypływające z „miłości synowskiej” Japonia przejęła od Chin na przełomie VI i VII wieku. Cnota Xiao uległa w Kraju Kwitnącej Wiśni transformacji dopasowując się do japońskiej struktury rodzinnej. W Chinach do dziś rodzinna lojalność rozciąga się na cały klan, który może liczyć dziesiątki tysięcy ludzi. W Japonii „miłość synowska” ogranicza się do najbliższej rodziny i rzadko obejmuje kogoś więcej niż ojca i dziadka oraz ich dzieci z potomstwem ${ }^{16}$. Jednak nawet $\mathrm{w}$ dzisiejszych czasach ojciec dorosłych Japończyków nie dokona żadnej decyzji bez zgody dziadka, jeśli ten oficjalnie nie zrzekł się obowiązków „głowy rodziny”. Rodzice aranżują i zrywają małżeństwa nawet trzydziesto- i czterdziestoletnich dzieci ${ }^{17}$.

Wewnątrz konfucjańskiej wspólnoty rodzinnej granice między poszczególnymi jednostkami rozmywają się. Podczas gdy w rozumieniu cywilizacji zachodniej zasadnicza granica dzieli jednostkę od wszystkich innych osób, w chińskim schemacie „trzech koncentrycznych kół” linia zasadniczego podziału otacza jednostkę wraz z jej bliskimi oddzielając ów swoisty „podmiot zespolony” grubą linią od podmiotów zewnętrznych ${ }^{18}$. Zgodnie z myślą filozofa Zhu Xi członkowie kolejnych generacji stanowią ,ucieleśnienie tego samego ciała rodziny”. Jak fale morza są ciągle tą samą wodą wybiegającą na brzeg ${ }^{19}$. Wewnątrz rodziny wyraźnie zarysowała się określona hierarchia. Pozycja członka tej wspólnoty zależała od jego wieku, płci, rangi społecznej, samodoskonalenia oraz dokonań. Ogromne znaczenie miało przestrzeganie zasad etykiety.

Funkcjonowanie w rodzinie konfucjańskiej, jak przyznaje Tu Weiming, było tożsame z nauką rytuałów. „Nieszczęścia chińskich rodzin tkwiących w autorytarnej władzy trzech więzi (ojca nad synem, władcy nad poddanym, męża nad żoną) były wnikliwie krytykowane przez niektórych sławnych i wpływowych pisarzy współczesnych Chin. Opowiadanie Rodzina Ba Jina (...) cierpko przypomina nam, że konfucjańska idea domu z perspektywy współczesnej świadomości, kształtowanej przez zachodnie idee liberalnej demokracji, jest współcześnie więzieniem odmawiającym podstawowych praw jednostkom, krępującym twórczą energię młodości”20. Rodzi-

\footnotetext{
${ }^{16}$ W Chinach wszyscy członkowie klanu utrzymują wspólne rodowe sanktuaria, w których spotykają się w określone dni by oddać cześć tysiącowi tabliczek z imionami zmarłych, pochodzących od wspólnego przodka. W Japonii kult odległych przodków nie istnieje. Japońskie rodziny czczą w domowym sanktuarium sześciu do siedmiu niedawno zmarłych członków rodziny. Nawet na cmentarzu nie odnawia się napisów na grobach prapradziadków i trzecie pokolenie przodków szybko odchodzi w niepamięć.

${ }^{17}$ Ruth Benedict, Chryzantema i miecz..., s. 55-58.

${ }^{18}$ Yang Guoshu, Xu Anbang, Psychologia i zachowanie Chińczyków, s. 155, za: Krzysztof Gawlikowski, Dwie cywilizacje..., s. 19.

${ }^{19}$ Ibidem, s. 14.

${ }^{20} \mathrm{Tu}$ Weiming, Rodzina, naród $i$ świat: Etyka globalna jako współczesne wyzwanie konfucjanizmu, w: Chiny: Przemiany państwa i społeczeństwa w okresie reform 1978-2000, red. K. Tomala, TRIO-ISP PAN, Warszawa 2001, s. 95.
} 
na w rozumieniu konfucjańskim jako wysoce zinstytucjonalizowana (posiadała często swoistą konstytucję, własne świątynie, szkoły, sądy, czasem też oddziały zbrojne) wielopokoleniowa wspólnota rodowa, mogąca liczyć nawet kilkadziesiąt osób, stała się wzorem dla wielu innych systemów organizacji społecznej tj. państwo, firma, partia polityczna.

Li Yunlong z organizacji „Human Rights China” uważa, że współcześnie funkcjonującą w Azji Wschodniej instytucję społecznych rytuałów, która określa nie tylko formy zachowań, ale reguluje też stosunki międzyludzkie i obowiązki etyczne, można porównać do zachodnich praw człowieka, ponieważ jest to stosunek dwustronny, niepoddańczy, choć wpisany w piramidę społeczną, w którym każda ze stron ma określone obowiązki. Fakt niedopełnienia ich przez jedną z nich nie zwalnia drugiej od odpowiedzialnego postępowania ${ }^{21}$.

\section{Indywidualistyczna koncepcja człowieka a kolektywistyczne pojmowanie jednostki}

W przeciwieństwie do tradycji protestanckiej, która traktuje indywiduum jako „izolowaną całostkę”, w myśli konfucjańskiej jednostka jest „,entrum sieci stosunków społecznych", a jej godność warunkowana jest udziałem w interakcjach międzyludzkich ${ }^{22}$. Powyższą teorię potwierdza Roger Ames z Uniwersytetu Hawajskiego, według którego jednostka „typu konfucjańskiego” nie tworzy autonomicznej i niezmiennej „całostki - atomu”, jak na Zachodzie”, lecz powinna być analizowana według schematu: punkt skupienia - pole oddziaływań. Nie jest, zatem ani autonomiczna, ani nie ma sztywnych granic ${ }^{23}$. Wartość człowieka możliwa jest do osiągnięcia jedynie w interakcji z innymi ludźmi poprzez harmoniczne i zgodne współdziałanie w imię wspólnego dobra, a także odpowiednio do wymagań innych oraz warunków aktualnej sytuacji. Niezbędne jest też poskramianie egoistycznych dążeń, nie ujawnianie własnych pragnień oraz tłumienie ich w sobie. Tradycja konfucjańska traktuje człowieka jako nierozłączną część kolektywu, mającą podrzędne znaczenie względem współtworzonej przez siebie grupy, dlatego interes wspólnoty stawiany jest wysoko ponad indywidualne potrzeby jednostki. Jednostka nie jest mniej ważna niż wspólnota, ale jest „ważna inaczej”. Nie jest też autonomiczna, lecz unikatowa, o własnym niepowtarzalnym statusie (osadzona w hierarchii rang społecznych). Według Amesa ,im bardziej człowiek jest

${ }^{21}$ Li Yunlong, Cultural Pluralism and Universal Human Rights - http:www.humanrights-china.org, s. 4-5, za: Katarzyna Barcikowska-Gruchalska, Koncepcja uniwersalizmu praw człowieka, „Sprawy Międzynarodowe”, lipiec-wrzesień 2003.

${ }^{22} \mathrm{Tu}$ Weiming, Confucian ethics today: The Singapore challenge, Curriculum Development Institute of Singapore, Singapore 1984, s. 80.

${ }^{23} \mathrm{Na}$ Rogera Amesa powołuje się K. Gawlikowski, w: Dwie cywilizacje..., s.16-17. 
indywidualistyczny, tym mniej jest on pełną i wartościową osobowością". Twierdzi on, że tym, co „odróżnia człowieka od istoty zaledwie człekokształtnej” jest jego „kulturowe i moralne samodoskonalenie i uspołecznienie”. W tym kontekście głównym budulcem człowieczeństwa jest rytuał, a jego przestrzeganie jest „,samoistną wartością”. $Z$ tego powodu Ames nazywa społeczeństwo konfucjańskie „rządzonym przez rytuał" 24 .

Jednostka może stać się w pełni ludzka jedynie wewnątrz wspólnoty. Poprzez uczestnictwo w rodzinnej, wiejskiej, a współcześnie państwowej strukturze organizacyjnej człowiek utrzymuje kontakt z transcendencją. Państwo poprzez swą działalność wychowawczą występuje jako łącznik istoty ludzkiej z bezosobową siłą moralną nazywaną w konfucjanizmie Niebem. Wyrastająca z tradycji chińskiej „orientacja społeczna” jednostki jest skutkiem wpajanej od dziecka zasady, iż człowiek jest przez całe życie integralną częścią rodziny. Ta pierwotna zależność przekłada się w późniejszych fazach życia na lojalność wobec zwierzchników, jak również posłuszeństwo i bezkrytyczny szacunek dla władz. Konfucjusz zalecał trzymanie się przeciętnych obywateli z dala od polityki. Uważał że władców należy stawiać ponad wszelką krytyką, ponieważ wyposażeni w moralną wolę od Niebios są w stanie najlepiej rozpoznać interesy ludu i zabezpieczyć je. Ten, komu nie powierzono stanowiska, nie powinien troszczyć się o to, jak powinno się je sprawować 25 .

Ze „społeczną orientacją" jednostki łączy się problem „wolności” oraz „praw” jednostki. W krajach zdominowanych przez konfucjanizm aż do czasów najnowszych nie znano (zarówno pod względem ideowym, jak i językowym) żadnego z tych terminów. „Czy chińska klasyczna myśl etyczno-polityczna może być uzasadnieniem dla przestrzegania albo też łamania praw człowieka?" - pyta w artykule pt. „Konfucjanizm a prawa człowieka” Jerzy Abkowicz. Według pism Konfucjusza i jego następców aż do przełomu XIX i XX poddany cesarza Chin miał do spełnienia wyłącznie obowiązki. Przejęte z języków europejskich oraz japońskiego terminy tj. ,prawa”, ,,demokracja”, ,,wolność” zostały dostosowane do języka chińskiego za pomocą przekładu objaśniającego znaczenie obcych pojęć. Specyfika języka chińskiego sprawiła, że pojęcia przejmowane z języków zachodnich zaczynały „żyć własnym życiem”, ponieważ mimowolnie każdy ze znaków nowego terminu odczytywano zgodnie z przyjętą w lokalnej kulturze treścią. Quanli czyli „prawa”, interpretowano jako „prawa i obowiązki płynące z władzy”. Natomiast Ren Quan - „prawa człowieka”, tłumaczono najczęściej „człowiek i władza”26. Louis Henkin, profesor prawa na Uniwersytecie Columbia w Nowym Yorku, potwierdza, że ani konfucjanizm klasyczny, ani cesarski, ani współczesny postkonfucjanizm „nie

\footnotetext{
${ }^{24}$ Zob. dalej.

${ }^{25}$ K. Czyżewska-Madajewicz, Dialogi konfucjańskie, Ossolineum, Warszawa 1976, s. 121.

${ }^{26}$ Jerzy Abkowicz, Konfucjanizm a prawa człowieka, „Azja-Pacyfik” 1999, t. 2, s. 251-252.
} 
mają wiele punktów stycznych z ideami praw człowieka". Niemniej jednak nie wyklucza możliwości przyszłej ewolucji myśli postkonfucjańskiej w kierunku zbliżającym ją z zachodnimi ideami praw człowieka ${ }^{27}$.

Podczas gdy cywilizacja zachodnia rozwijała koncepcję „wolności zewnętrznej” od ograniczeń i restrykcji nakładanych przez państwo, w Azji Wschodniej poszukiwano „wolności wewnętrznej”, czyli rozwoju własnego ,ja”, eliminacji wewnętrznych ograniczeń i niedoskonałości, osiągnięcia szczęścia i pogody ducha ${ }^{28}$. Wartość tę można było osiągnąć na drodze samodoskonalenia. „Wolność promowana w etyce konfucjańskiej polega na swobodzie czynienia dobra, czy też na wolności wyboru tego, co dobre. Jest to etyczna wolność wyboru, miała jednak ona swój zakres i ograniczenia. Jest to zatem tylko ograniczona wolność" ${ }^{29}$. $Z$ tego powodu możliwe jest - a nawet wskazane - ograniczenie przez władze wolności jednostki, gdyż to właśnie do nich należy określenie tego, co dobre.

„Prawa są nadawane jednostce przez społeczeństwo i to ono jest źródłem praw (...) w razie potrzeby może ono [społeczeństwo - przyp. MK] je także odebrać, albo przynajmniej ograniczyć ich zakres" ${ }^{30}$. Zarówno w tradycji konfucjańskiej jak i buddyjskiej porządek społeczny opiera się na nauczaniu jednostek ich obowiązków i powinności, nie zaś wypracowaniu systemu indywidualnych praw. Dlatego ukształtowanie „osobowości demokratycznej” w krajach Azji Wschodniej jest wyjątkowo trudnym zadaniem. Wprowadzenie zasad wolności oraz praw człowieka wymaga wcześniejszego „ukształtowania podmiotowości indywidualnej, określenia pola własnych interesów oraz przeciwstawienia siebie samego zbiorowości". Problem w tym, że sprzeciw wobec podporządkowaniu grupie stoi w sprzeczności z „dążeniem do ścisłych związków ze zbiorowością"”1.

\section{Relacje między człowiekiem a społeczeństwem ${ }^{32}$}

Jeden z najwybitniejszych znawców konfucjanizmu, Tu Weiming z Uniwersytetu Harvarda, skontrastował podstawowe założenia ideologii protestanckiej właściwej państwom zachodniego kapitalizmu z filozofią konfucjańską, która jest podstawą systemów politycznych Azji Wschodniej. W efekcie zarysowały się wy-

\footnotetext{
${ }^{27}$ Ibidem, s. 152.

${ }^{28}$ K. Gawlikowski, Dwie cywilizacje..., s.17.

${ }^{29}$ Hsieh Yu-Wei, The status of the individual in Chinese ethics, za: K. Gawlikowski, Problem praw człowieka z perspektywy azjatyckiej, „Azja-Pacyfik” 1998, t. 1, s. 21-22.

${ }^{30} \mathrm{Wu}$ Jingxiong, Studia o filozofii prawa, cyt. za: K. Gawlikowski, Problem praw człowieka..., s. 22.

${ }^{31}$ Yang Guoshu, Huang Guangguo, Psychologia i zachowanie Chińczyków, s. 9, za: K. Gawlikowski,, Problem praw czlowieka..., s. 23.

${ }^{32}$ Na systematykę Tu Weiminga powołuje się prof. K. Gawlikowski, ibidem, s. 20-23.
} 
raźne różnice między spojrzeniem każdej z cywilizacji na stosunki między jednostką a społeczeństwem.

- W cywilizacji zachodniej jednostka przedstawiana jest jako indywiduum, które w celu zwiększenia swej niezależności przecina więzy rodzinne i funkcjonuje w społeczeństwie jako kompletna i izolowana od innych ludzi „samoistna całostka". Natomiast w cywilizacji Azji Wschodniej pojedynczy człowiek przez całe życie pozostaje centrum sieci stosunków rodzinnych i społecznych, zaś jego godność uzyskiwana jest na gruncie międzyludzkich interakcji. Według nauk Konfucjusza każdy człowiek rodzi się równy w predyspozycjach, lecz swoją wartość oraz znaczenie wypracowuje dopiero w interakcjach z innymi ludźmi ${ }^{33}$. Granice między jednostką a jej otoczeniem są płynne. Widać to wyraźnie na przykładzie konstrukcji japońskiego „ja”, ukształtowanego pod wpływem nauk buddyzmu. Tożsamość Japończyka składa się z trzech warstw jednostkowego ,ja”: interakcyjnego, wewnętrznego oraz bezgranicznego tj. ,pustego”, ,pozbawionego ego”, ,czystego" poprzez brak egoistycznych motywów, manifestowana się w samopoświęcaniu dla innych lub dla jakiejś sprawy ${ }^{34}$.

- Zatomizowanych obywateli państw zachodnich charakteryzuje wysoka świadomość własnych praw oraz gotowość do ich obrony, a także determinacja w realizacji indywidualnych interesów. „Człowiek grupowy” skupia się dla odmiany na własnych obowiązkach i powinnościach oraz manifestuje chęć współpracy z innymi ludźmi, jak również umiejętność współdziałania wewnątrz grupy. Realizując cele kolektywne jednostka podnosi swój prestiż w ramach wspólnoty.

- Niski poziom rytualizacji życia społecznego społeczeństw Zachodu wiąże się z brakiem jednoznacznego rozróżnienia na zachowania właściwe i nieprawidłowe, co implikuje większą swobodę jednostki oraz jej tolerancję względem zachowań odbiegających od normy. Na obszarach zdominowanych przez myśl konfucjańską społecznie akceptowane wzorce są precyzyjnie określone. Dominuje tam wysoki poziom zrytualizowania zachowań oraz brak tolerancji wobec działań i poglądów nie zgodnych ze sztywnymi regułami. Dla uniknięcia konfliktów społecznych interakcje międzyludzkie wyznaczone są przez precyzyjnie określone wzorce. Wpajane od najmłodszych lat reguły postępowania dają pewność jak w danej sytuacji należy się zachować. Zakorzenione w zbiorowej świadomości standardy zachowań przestrzegane są spontanicznie.

\footnotetext{
${ }^{33}$ Karin Tomala, Ewolucja idei praw człowieka w kręgu chińskich elit politycznych, w: Uniwersalizm praw człowieka, op. cit., s. 231-248.

${ }^{34}$ K. Gawlikowski, Problem praw człowieka..., s. 18.
} 
- Na Zachodzie stosunki społeczne kształtują się w ramach tzw. „systemu przeciwników", który gwarantuje i chroni prawa jednostki, uznaje jej indywidualne potrzeby oraz interesy, popiera i stymuluje międzyludzkie współzawodnictwo i konkurencję. Natomiast w kulturze konfucjańskiej funkcjonują „wspólnoty zaufania”. Podkreśla się tam znaczenie wartości, które (z uwzględnieniem hierarchii) są szanowane przez wszystkie jednostki w ramach wspólnoty. W przeciwieństwie do „antagonistycznego systemu” Zachodu, we „wspólnotach zaufania” potępia się współzawodnictwo oraz spory oraz promuje współpracę i dążenie do konsensusu.

Według K. Gawlikowskiego, ,implikacje tak odmiennego samookreślenia się jednostki w stosunku do zbiorowości są znaczące, szczególnie w odniesieniu do praw człowieka, dotyczących głównie jednostki oraz mających bronić jej interesów. Jeśli nie jest ona autonomicznym podmiotem, gotowym przeciwstawić się zbiorowości oraz władzom, a dąży do udziału w podmiotowości zbiorowej, do działania w warunkach zgody z innymi, jak również do podporządkowania się normom kolektywu oraz wszelkim władzom, potrzeba zapewnienia jej wolności w powyższych dziedzinach traci na znaczeniu. W tej sytuacji na czoło wysuwają się potrzeby społeczne, jak również do pewnego stopnia kwestie obrony praw kolektywów wyłamujących się z dyscypliny zbiorowej, buntujących się przeciwko oficjalnej ideologii czy polityce państwa" ${ }^{35}$.

\section{Determinanty azjałyckiej wizji praw człowieka ${ }^{36}$}

Specyfika konfucjańskiej tradycji politycznej, która determinuje podejście do praw człowieka w Azji Wschodniej dotyczy czterech podstawowych stref:

- kolektywistycznego podejścia do jednostki;

- braku tradycji prawa;

- funkcji i struktury państwa oraz stosunku do niego;

- niskiego poziomu aspiracji politycznych ludności ${ }^{37}$.

Na strefy te powołuje się Roman Kuźniar pisząc, że o ile w Ameryce Łacińskiej, Afryce, czy świecie arabskim w dziedzinie praw człowieka mają miejsce przykłady naśladownictwa, z uwzględnieniem regionalnej specyfiki, o tyle w Azji mamy do czynienia z odmienną sytuacją. „Cywilizacyjna specyfika regionu (...) stanowi podstawę do formułowania alternatywnych wobec zachodnich koncepcji praw człowieka" 38 .

\footnotetext{
${ }^{35}$ K. Gawlikowski, Problem praw czlowieka..., s. 23.

${ }^{36}$ Systematyka zaczerpnięta z tekstu K. Gawlikowskiego, Problem praw człowieka ..., s. 1-40.

${ }^{37}$ Ibidem.

${ }^{38}$ Roman Kuźniar, Prawa człowieka: prawo, instytucje, stosunki międzynarodowe, Wyd. Naukowe „Scholar”, Warszawa 2002, s. 214.
} 
Z kolei Krzysztof Gawlikowski podkreśla, że podczas gdy w tradycji zachodniej państwo było postrzegane jako potencjalne zagrożenie dla jednostki, w Azji Wschodniej ucisk wobec jednostki pochodził ze struktur niższego rzędu. W drugim przypadku centralne władze państwowe postrzegane były jako obrońca ludności przed represjami ze strony struktur lokalnych. Ponadto, z uwagi na to, że władze były odpowiedzialne $\mathrm{m}$.in. za dobrobyt jednostki, akceptowany był niedopuszczalny w kulturze zachodniej interwencjonizm, który sprowadzał się także do ingerencji w sferę prywatną jednostki.

Jako ostatnią sferę K. Gawlikowski wymienia niski poziom aspiracji politycznych ludności, czego wyrazem jest brak pluralizmu politycznego, różnorodności opcji ideowo politycznych oraz polityczna apatia społeczeństwa. W większości agrarne społeczeństwa azjatyckie nigdy nie brały aktywnego udziału w działalności politycznej. W konsekwencji państwowa struktura polityczna funkcjonuje w autonomii wobec społeczeństwa ${ }^{39}$.

\section{Międzycywilizacyjny dialog na temat praw człowieka i podstawowych wartości}

W międzycywilizacyjnym dialogu na temat idei praw człowieka największym problemem jest - wynikająca $\mathrm{z}$ fundamentalnych różnic $\mathrm{w}$ systemach wartości bariera kulturowa. Koncepcja praw człowieka dotyczy autonomicznej jednostki, jej wolności oraz praw, podczas gdy, jak wyraźnie wynika z powyższych rozważań, każda z tych idei jest kulturowo obca cywilizacji Dalekiego Wschodu.

Najstarsze koncepcje oraz wzorce kulturowe, wywodzące się z kręgu cywilizacji basenu Morza Śródziemnego oraz Azji Wschodniej, wydają się być zaskakująco podobne. $\mathrm{Z}$ biegiem czasu nastąpiło radykalne oddalenie się od siebie dwóch cywilizacji, ponieważ każda z nich rozwijała się w innym kierunku - indywidualistycznym na Zachodzie oraz kolektywistycznym w Azji Wschodniej. Z kolei na początku XXI w. widać ich ponowne zbliżenie spowodowane z jednej strony procesami okcydentalizacji Azji Wschodniej, a z drugiej przejmowaniem przez Zachód pewnych wzorców z kultury duchowej Dalekiego Wschodu. Biorąc pod uwagę historyczne relacje między tymi cywilizacjami zauważyć można ich wzajemne na siebie oddziaływanie. Ta pierwsza czerpała z Azji w XIX w. rozwiązania techniczne i modele organizacyjne (głównie odnoszące się do struktur państwowych), które stworzyły podstawy dla rozwoju współczesnej cywilizacji Zachodu. Później to Azja stała się odbiorcą dobrodziejstw w zachodniej rewolucji technicznej oraz przejmowała (choć znacznie modyfikując) rozwiązania systemów demokratycznych zrodzonych na gruncie zachodniego kapitalizmu.

\footnotetext{
${ }^{39}$ K. Gawlikowski, Problem praw człowieka ..., s. 26-40.
} 
Konkludując, obydwie cywilizacje pod względem rozwoju okazały się na przestrzeni wieków komplementarne. Jednak w sferze podstawowych wartości wzajemne oddziaływanie było nieporównywalnie słabsze, dlatego aż do dziś każda z cywilizacji zachowała swą unikalną tożsamość, która determinuje specyfikę rozwiązań gospodarczych i politycznych oraz porządkowanie i interpretację systemów podstawowych wartości, co w szczególny sposób widoczne jest przy formułowaniu katalogów praw i obowiązków człowieka ${ }^{40}$.

W wyniku zakończenia zimnej wojny pojawiły się w myśli zachodniej prognozy dotyczące rozwoju nowego porządku międzynarodowego. Wydaje się, że idealistyczna teoria Francisa Fukuyamy ${ }^{41} \mathrm{o}$ „końcu historii”, głosząca światowy triumf liberalnej demokracji, poniosła sromotną klęskę. O ile kraje Azji Wschodniej skłonne są w imię rozwoju ekonomicznego przejmować rozwiązania kapitalistycznej gospodarki rynkowej oraz niektóre modele organizacji państwowej (z uwzględnieniem znacznej modyfikacji i dostosowania do lokalnych warunków), o tyle model zachodniej demokracji liberalnej w czystej formie nie okazał się na gruncie azjatyckim wariantem ani optymalnym, ani powszechnie przyswajalnym. Również katastroficzna wizja zderzenia cywilizacji Samuela Huntingtona ${ }^{42}$, która zakłada nieunikniony konflikt na obszarach styczności cywilizacji światowych, nie stanowi realnej opcji rozwoju stosunków międzynarodowych.

Michael Freeman stawia tezę, że zarówno prognoza zderzenia cywilizacji, jak i teoria ,azjatyckich wartości”, mimo iż obie błędne, to jednak mogą okazać się niebezpieczne ${ }^{43}$ - pierwsza z punktu widzenia pielęgnowania antagonizmów międzykulturowych, druga zaś przez wzgląd na utrudnianie dialogu na temat budowy systemu powszechnych, ogólnoludzkich praw człowieka, które czerpać powinny z najlepszych wartości zachodniej i dalekowschodniej tradycji. Reasumując, Freeman stoi na stanowisku, że ludzie mogą dążyć do samookreślenia poprzez wyrażanie solidarności (a nie wrogości) względem członków innych cywilizacji m.in. poprzez poszukiwanie w kulturowej różnorodności tego, co wspólne, zarówno na polu kształtowania stosunków międzynarodowych, jak i w sferze wartości ${ }^{44}$.

\footnotetext{
${ }^{40} \mathrm{~K}$. Gawlikowski, Dwie cywilizacje i ich wizje czlowieka ..., s. 4-6; 28-29.

${ }^{41}$ Francis Fukuyama, Koniec historii, Zysk i S-ka, Poznań 1997 oraz Ostatni człowiek, Zysk i S-ka, Poznań 1997.

${ }^{42}$ Samuel P. Huntington, Zderzenie cywilizacji i nowy ksztalt tadu światowego, Muza, Warszawa 2003.

${ }^{43}$ Michael Freeman, Human Rights, Asian Values, and the Clash of Civilization, "Issues \& Studies", $1998 \mathrm{nr}$ 10, s. 53.

${ }^{44}$ Ibidem, s. 44-78.
} 
Dwie cywilizacje...

\section{Geneza poięcia praw człowieka w cywilizacii konfucjańskiej}

Termin „prawa człowieka” pojawił się w piśmiennictwie chińskim w $1898 \mathrm{r}$. Jednak już znacznie wcześniej Chińczycy, nie wytwarzając co prawda samego pojęcia praw przynależnych jednostce, uświadamiali sobie znaczenie człowieka oraz potrzebę jego obrony. Już w 1848 r. pojawiła się w Chinach krytyka wywozu ludności afrykańskiej do Ameryki, a od drugiej połowy XIX w. pojawiło się coraz więcej publikacji na temat praw kobiet. Wang Erh-min, tajwański uczony, dowodzi, że człowiek został doceniony w każdej z trzech myśli filozoficznych Azji Wschodniej, czyli konfucjanizmie (samodoskonalenie i pielęgnowanie cnót), taoizmie (ochrona życia prowadząca do długowieczności, zakładająca miłość i szacunek jednostki) oraz moizmie (głoszenie miłości i powstrzymania się od stosowania siły militarnej dla zapewnienia harmonii i powodzenia ludzi). Jednakże pojawienie się dojrzałej świadomości praw człowieka wśród dalekowschodnich myślicieli w największym stopniu inspirowane było hasłami misjonarzy katolickich, którzy zgodnie z Biblią głosili, iż „wszyscy ludzie rodzą się równi”"

Wobec niechęci większości krajów regionu nie udało się zrealizować podejmowanych (przez Komisję Społeczno-Ekonomiczną dla Azji) na forum ONZ wysiłków w celu stworzenia w Azji Wschodniej regionalnego systemu praw człowieka. Pozostałe inicjatywy mają charakter pozarządowy i subregionalny zasięg. W ramach organizacji kilkunastu krajów wschodniej Azji oraz zachodniego Pacyfiku od 1979 r. funkcjonuje Stały Komitet Praw Człowieka ${ }^{46}$.

Brak systemu regionalnego na jednym z największych oraz najbardziej dynamicznych gospodarczo regionów świata nie oznacza, że nie podejmowano prób jego stworzenia, szczególnie kiedy po zakończeniu zimnej wojny środowisko międzynarodowe naciskało na państwa Azji Wschodniej w kwestii zajęcia wspólnego stanowiska wobec problematyki praw człowieka. W 1992 r. kraje ASEAN wyszły z inicjatywą stworzenia Komisji Praw Człowieka, której ustanowienie umożliwiłoby organizacji wypracowanie i prowadzenie wspólnej polityki w dziedzinie praw człowieka, odpowiadającej historycznym, ekonomicznym oraz politycznymh uwarunkowaniom regionu. Komisja ta miała z czasem objąc swym zasięgiem obszar całej Azji ${ }^{47}$.

Wobec braku regionalnego systemu ochrony praw człowieka na poziomie międzyrządowym ogromne znaczenie mają inicjatywy podejmowane przez organizacje

${ }^{45}$ R. Sławiński, Rola jednostki w spoleczeństwie konfucjańskim, w: Uniwersalizm praw człowieka..., s. 20-21.

${ }^{46}$ K. Yamazaki, Ochrona praw człowieka w krajach azjatyckich, „Sprawy Międzynarodowe”, 1990, nr 6.

${ }^{47}$ James T. H. Tang : A Clash of Values? Human Rights in The Post - Cold War World - wykład podczas konferencji zatytułowanej: “Asian Values” and Democracy in Asia, która odbyła się w Japonii 28 marca 1997 r.; zob. www.unu.edu/unupress/asian-values.html. 
pozarządowe. Najważniejszą rolę w regionie odgrywają: Lawasia (Stowarzyszenie Prawnicze dla Azji i Pacyfiku), Azjatycka Komisja Praw Człowieka oraz Azjatyckie Centrum Pomocy Prawnej. Ochroną praw człowieka zajmują się też Azjatyckie Centrum Rozwoju Narodów, Azjatycka Regionalna Giełda Nowych Alternatyw (The Asian Regional Exchange for New Alternatives), Forum Azji-Pacyfiku ds. Kobiet, Prawa i Rozwoju oraz Azjatyckie Stowarzyszenie Studentów.

Najbardziej aktywną pośród organizacji pozarządowych pozostaje Lawasia, która składa propozycje konkretnych rozwiązań instytucjonalnych. Zaproponowała ona zestaw 10 podstawowych zasad ochrony praw człowieka oraz model „Pacyficznej Karty Praw Człowieka”, w 1988 r. zarekomendowała ustanowienie regionalnego instytutu ds. badania praw człowieka monitorującego nadużycia w tej dziedzinie, a w 1993 r. zaproponowała utworzenie Komisji oraz Trybunału zajmujących się prawami człowieka ${ }^{48}$. W zakresie monitorowania postępów przestrzegania praw człowieka oraz informowania o naruszeniu wolności jednostek na terenie Azji Wschodniej działają obecnie liczne zachodnie organizacje pozarządowe jak Human Rights Watch, Amnesty International czy Freedom House.

\section{Uniwersalny model praw człowieka zachodniego typu}

Promowany przez świat zachodni system praw człowieka zrodził się na gruncie tradycji judeochrześcijańskiej oraz w wyniku specyficznych doświadczeń historycznych regionu euroatlantyckiego. II Wojna Światowa była okresem największego w historii pogwałcenia praw człowieka. Tragiczne doświadczenia tamtej epoki udowodniły istnienie bezpośredniej zależności pomiędzy respektowaniem elementarnych praw człowieka a utrzymaniem pokoju i przyjaznych stosunków między państwami ${ }^{49}$. Przełomowe znaczenie miała instytucjonalizacja wyznawanych przez Zachód wartości w postaci Organizacji Narodów Zjednoczonych, której członkowie zobowiązali się do „powszechnego poszanowania”, ,popierania”, ,przestrzegania” ,praw człowieka i podstawowych wolności” oraz „godności i wartości jednostki”. W 1948 r. idea równości jednostek, niezależnie od rasy, wyznania, języka, płci oraz opinii politycznej sformalizowana została w postaci systemu praw człowieka zawartych w Powszechnej Deklaracji Praw Człowieka, a następnie została uszczegółowiona w dwóch konwencjach z $1966 \mathrm{r}^{50}$ Od tej pory dyskusje o prawach człowieka toczą się na temat ich interpretacji oraz przestrzegania. Problem uniwersalnej definicji praw człowieka oraz jednoznacznego określenia ich zakresu leży w omówionych wcześniej odmiennościach cywilizacyjnie zdeterminowanych

\footnotetext{
${ }^{48}$ Ibidem.

${ }^{49}$ R. Kuźniar, Prawa człowieka..., s. 58-60.

${ }^{50}$ Akira Iriye, The End of the Century: Emerging Themes, Disappearing Themes, "Issues \& Studies", $1998 \mathrm{nr}$ 10, s. 15.
} 
systemów wartości. „Argument, że możemy instynktownie rozpoznać i uzgodnić to, co stanowi transcendentny, główny zespół praw człowieka, choć pociągający, zderza się z realiami ich kwestionowania w innych kulturach i przez inne osoby w naszej własnej kulturze" 51 .

Trudno się nie zgodzić z faktem, ze w różnych regionach świata myśl polityczna i społeczna rozwijała się w odmienny sposób. Jednak według zwolenników uniwersalizmu praw człowieka ten zróżnicowany rozwój w niczym nie zaprzecza istnieniu podstawowych standardów tych praw, jednakowych w każdym czasie i miejscu. Mogą być realizowane w różny sposób, ale ich istota się nie zmienia. Nie zostały narzucone przez nikogo z góry - są uniwersalne, ponieważ wypływają z uniwersalnych potrzeb. Strach, głód, cierpienie psychiczne i fizyczne nie zależą od żadnego kontekstu kulturowego. Uniwersalizm nie oznacza, że na całym świecie zapanuje powszechna zgoda na jednolite standardy praw człowieka. Podstawowe prawa zawarte w Powszechnej Deklaracji Praw Człowieka mają wymiar uniwersalny dlatego, że definiują uniwersalne interesy słabszych na całym świecie. Ich uniwersalizm przejawia się przede wszystkim w tym, że wyrażają potrzeby i żądania lokalne, które istniały zawsze. Prawa człowieka to jedna z najważniejszych zdobyczy myśli zachodniej. Stanowią one bowiem jedyną i zarazem rzeczywistą nadzieję dla jednostek buntujących się przeciwko uciskowi i poniżaniu, jakich doznają w różnych rejonach świata, jedyną legitymizację ich buntu ${ }^{52}$.

Krytycy podejścia uniwersalistycznego twierdzą, że jest ono produktem jednej tylko kultury i dlatego nie posiada legitymacji w pozostałych warunkach cywilizacyjnych. Bazujące na społeczno-politycznym dorobku Zachodu dokumenty dotyczące ochrony praw człowieka składają się z pojęć i zwrotów, które nie są zrozumiałe dla ludzi, którzy nie wychowali się w kręgu grecko-rzymskiej cywilizacji. Michael Ignatieff wyróżnia trzy najbardziej aktywne grupy promujące zasadę relatywizmu kulturowego czyli anty-uniwersalnego podejścia do praw człowieka: odradzający się islam, myśliciele zachodni oraz kultura Azji Wschodniej ${ }^{53}$.

Uniwersalizm praw człowieka kwestionuje część zachodnich naukowców, którzy podzielając przekonania radykalnych relatywistów Adamantii Pollis i Petera Schwaba uważają prawa człowieka za "zachodni twór o ograniczonym zastosowaniu” oraz „dwudziestowieczną fikcję”, która wyrosła z tradycji prawnej Stanów Zjednoczonych, Wielkiej Brytanii oraz Francji i jest niemożliwa do zrealizowania w kulturach, dla których pojęcie liberalnego indywidualizmu jest historycznie obce. Relatywiści oskarżają uniwersalistów o skłonność do,,intelektualnej hegemonii”, która wyraża się w ,języku praw człowieka”, a której istotą jest neoko-

${ }^{51}$ Dilys M. Hill, Human Rights and Foreign Policy: Theoretical Foundation, za: K. Gawlikowski: Problem praw czlowieka..., s. 9.

${ }^{52} \mathrm{~K}$. Barcikowska-Gruchalska, Koncepcja uniwersalizmu..., s. 72-75.

${ }^{53}$ Michael Ignatieff, The Attack on Human Rights, "Foreign Affairs", listopad-grudzień 2001, s. $106-109$. 
lonialna polityka Zachodu, który chce odzyskać utracone w wyniku dekolonizacji wpływy. Popularyzacja postmodernistycznego relatywizmu nie pozostaje bez wpływu na myślenie i działanie zachodnich obrońców praw człowieka, którzy coraz częściej wybierają kompromis w dialogu z reprezentantami odmiennego spojrzenia na kwestie praw człowieka.

Niechęć państw regionu Azji Wschodniej wobec obcego im pod względem kulturowym kodeksu praw podsyca wykorzystywanie przez Zachód haseł „ochrony podstawowych wolności" dla osiągania celów gospodarczych i politycznych. Nie bez wpływu jest również przeszłość kolonialna mocarstw zachodnich, które zaledwie kilka dekad temu łamały prawa człowieka bez pardonu na podległych sobie obszarach. Wyzwolone z niewolniczych więzów kraje oskarżają zachodnich głosicieli „fundamentalnych i powszechnych praw” o hipokryzję oraz imperializm kulturowy.

Podczas gdy opór krajów islamskich wobec adaptacji zachodnich wzorców praw człowieka można częściowo wytłumaczyć niepowodzeniem społeczeństw arabskich w korzystaniu z rozwoju gospodarki globalnej, państwa Azji Wschodniej bronią swojej tożsamości kulturowej w konsekwencji regionalnego sukcesu ekonomicznego. Liderzy takich państw jak Malezja czy Singapur mają dość odwagi, by odrzucić zachodnie wzory demokracji, indywidualnych praw i wolności, ponieważ udało się im z powodzeniem połączyć polityczny autorytaryzm z rynkowym kapitalizmem ${ }^{54}$.

Problem uniwersalizmu praw człowieka i związanych z nim uwarunkowań kulturowych zyskał szczególne znaczenie na początku lat 90. XX w., gdyż wówczas zimnowojenny spór ideologiczny Wschód-Zachód zastąpiony został problemem sprzeczności między cywilizacjami, które przekładały się na odmienne interpretowanie praw człowieka oraz przywiązywanie do nich różnej wagi. Rozwój gospodarczy i przejmowanie zachodnich technologii oraz instytucji i postępująca okcydentalizacja nie implikują zerwania z tradycją konfucjańską, jak to udowodniły Japonia, Tajwan, Hongkong, czy Singapur. Reasumując, oczekiwania Zachodu, że obecna postać systemu praw człowieka będzie w całej rozciągłości akceptowana i bezkrytycznie inkorporowana przez kraje innych cywilizacji wydaje się być nierealny ${ }^{55}$.

\section{7. „Wartości azjatyckie" jako alternatywa dla powszechnego systemu praw człowieka}

Ze względu na zachodni rodowód oraz euroatlantycką specyfikę kulturową, kraje innych niż zachodnia cywilizacji, chociaż uznają Powszechną Deklarację Praw

\footnotetext{
${ }^{54}$ Ibidem.

${ }^{55}$ K. Gawlikowski, Problem praw czlowieka..., s. 15-17
} 
Człowieka i akceptują istnienie jej zawartości, bardzo często odmiennie interpretują poszczególne prawa i nadają im odmienne znaczenie. Tendencja ta znalazła wyraz w ustaleniach konferencji z Bangkoku zorganizowanej w 1993 r. pod auspicjami ONZ. W uchwalonej tam deklaracji podkreślono jednoznacznie, iż mimo powszechnego i obiektywnego oraz w całej rozciągłości respektowanego charakteru praw człowieka, konieczne jest uwzględnienie specyfiki poszczególnych krajów ze względu na odmienności doświadczeń historycznych, tradycji kulturowych i religijnych. Zaznaczono też, iż prawa gospodarcze, społeczne i kulturalne są nierozłączne od praw obywatelskich i politycznych, zaś domaganie się ich respektowania nie może naruszać integralności terytorialnej i suwerenności poszczególnych państw ${ }^{56}$.

Niektóre spośród azjatyckich rządów m.in. Singapur, Chiny, Indonezja i Malezja wysunęły ,azjatycką koncepcję praw człowieka”. W uproszczeniu zakłada ona, iż pełen rozkwit praw politycznych i obywatelskich musi zostać poprzedzony przez rozwój ekonomiczny, ważniejsza jest harmonia we wspólnocie, a niżeli indywidualne wolności jednostki, poszczególne państwa powinny mieć możliwość interpretacji międzynarodowych standardów zgodnie z własną historią, kulturą, systemem politycznym oraz rozwojem ekonomicznym. Wyłonienie się koncepcji „azjatyckich wartości” ma duże znaczenie, ponieważ wyłożyła ona podstawowe założenia azjatyckiego systemu wartości (z podkreśleniem jego odmienności od systemu Zachodniego) oraz uzmysłowiła, w jaki sposób azjatyckie rządy postrzegają relację pomiędzy rozwojem a prawami człowieka. Po wnikliwej analizie podstawowe założenia tej koncepcji okazują się jednak sprzeczne. Chiny oraz Indonezja głoszą, że respektowanie praw indywidualnych jest naturalną konsekwencją rozwoju ekonomicznego, natomiast Malezja i Singapur podkreślają, że nawet w rozwiniętych społeczeństwach azjatyckich stabilizacja i porządek będą ważniejsze od ochrony indywidualnych praw jednostki ${ }^{57}$.

Chiny oświadczyły w Białej Księdze dotyczącej praw człowieka z 1991 r., że „dla każdego państwa czy narodu najważniejsze jest prawo do przetrwania, bez zapewnienia którego wszelkie inne prawa są bez znaczenia". Jednak, jak dowodzi indyjski ekonomista i filozof - Amartya Sen, zagwarantowanie przetrwania w dużej mierze zależy od swobody wypowiedzi oraz odpowiedzialności władz. Teoria ta ma swe odniesienie również w stosunku do Chin. Gdyby te w czasach Wielkiego Skoku nie czuły się w obowiązku milczeć na temat problemów z produkcją żywności, nie doszłoby do klęski głodu, w wyniku której zmarło w latach 1959-1961 około 15 milionów Chińczyków ${ }^{58}$.

\footnotetext{
${ }^{56}$ Ibidem, s. 16.

${ }^{57}$ Sidney Jones, Asian Human Rights, Economic Growth and United States Policy, "Current History" $1996 \mathrm{nr} 605, \mathrm{~s} .421$.

${ }^{58}$ Ibidem, s. 421-422.
} 
Władze Indonezji powtarzają za Chinami: „W większości krajów Azji ma miejsce sytuacja, w której - wobec niedostatecznego poziomu rozwoju - priorytetem jest zapewnienie najbardziej podstawowych praw ludu tj.: 'wykorzenienie analfabetyzmu, zmniejszenie ubóstwa, zapewnienie opieki zdrowotnej oraz kreacja zatrudnienia'. Powyższe stanowisko implikuje szereg pytań: W jaki sposób korzystać z prawa do swobody wypowiedzi będąc niepiśmiennym? Jak cieszyć się prawem własności żyjąc poniżej granicy ubóstwa? Po co łączyć się w związki zawodowe będąc bezrobotnym?"59.

Sidney Jones wykazuje błędy powyższego sposobu myślenia. Po pierwsze prawo do respektowania czy posiadania podstawowych praw obywatelskich nie powinno zależeć od statusu ekonomicznego lub poziomu edukacji. Rządy nie są w stanie zmniejszyć ubóstwa i zapewnić innych praw ekonomicznych bardziej efektywnie bez wolności wypowiedzi oraz partycypacji społeczeństwa w procesie podejmowania decyzji

Premierzy Singapuru (Lee Kuan Yew) i Malezji (Mahathir bin Mohammad) przyjęli odmienne stanowisko, niż liderzy ich większych i biedniejszych sąsiadów. Obydwaj utrzymują, iż nawet w przypadku wysokiego poziomu wykształcenia ludności, pewne ograniczenia swobody wypowiedzi powinny być utrzymane dla dobra społeczeństwa. Lee oświadczył: "uważam, że część systemu amerykańskiego jest zupełnie nieakceptowalna: broń, narkotyki, brutalna przestępczość, żebractwo. (...) Rozpowszechnienie praw, które upoważniają jednostkę do samowolnego zachowania dzieje się kosztem porządku społecznego. Na Wschodzie głównym celem jest zachowanie porządku społecznego, aby wszyscy ludzie mogli się cieszyć maksimum wolności." Lee dodaje, że wolność ta może istnieć jedynie w państwie prawa, w którym wyeliminowane są spory, niezgoda oraz anarchia ${ }^{60}$.

W konkluzji można stwierdzić, że wzrost ekonomiczny bez silnej interwencji państwowej oraz ograniczenia określonych praw może doprowadzić do załamania społeczeństwa, w sposób jaki to się dzieje na Zachodzie. Stwierdzenie to jest sprzeczne z czerpiącym z doświadczenia Tajwanu oraz Korei Południowej argumentem, że wzrost ekonomiczny implikuje postępujące otwieranie się społeczeństwa. Stanowisko singapurskie wynikać może z faktu, iż państwo to jest tak bogate, że argument o konieczności utrzymania autorytarnych form kontroli dla zapewnienia rozwoju ekonomicznego stracił rację bytu.

Bilahari Kausikan - inny singapurski urzędnik państwowy - wyjaśnia, dlaczego „dobry rząd”, nawet w rozwiniętym społeczeństwie musi stosować pewne ograniczenia praw, by zachować porządek a m.in. ograniczenia swobody wypowiedzi by uniknąć podgrzewania napięć etnicznych czy zwiększania podziałów społecz-

\footnotetext{
${ }^{59}$ S. Wiryono, Human Rights: Why the Confrontation?, "The Nation"(Bangkok), April 1, 1993.

${ }^{60}$ Fareed Zakaria, Culture is Destiny: A Conversation with Lee Kuan Yew, "Foreign Affairs", marzec-kwiecień 1994, s. 111.
} 
nych ${ }^{61}$. O ile do pewnego stopnia da się uzasadnić, że forma rządów autorytarnych była niezbędna dla podjęcia trudnych decyzji politycznych i ekonomicznych, które przyczyniły się do spektakularnego wzrostu gospodarczego w regionie, znacznie trudniej jest dowieść, że owe ograniczenie praw politycznych wymagało naruszeń praw obywatelskich tj.: rozpowszechnienie aresztowań z powodów politycznych, tortury czy masowe egzekucje. Bez możliwości społecznej krytyki władz oraz egzekwowania odpowiedzialności rządu i policji brakuje skutecznej kontroli nadużyć. Problem polega na tym, że niewielkie ilości autorytaryzmu szybko zmieniają się w poważne naruszenia - np. ograniczeniom politycznym często towarzyszą naruszenia cielesnej integralności. $Z$ tego powodu prawo materialne oraz zarządzenia, które czasowo ograniczają prawa obywateli w imię narodowego bezpieczeństwa i porządku publicznego, mogą być niebezpieczne, gdyż rodzi się duże prawdopodobieństwo ich instytucjonalizacji. W Indonezji, po puczu gestapu w 1965 r., utworzono Operacyjne Dowództwo dla Przywrócenia Porządku i Bezpieczeństwa, przemianowane później na Organ Koordynacyjny dla Utrzymania Stabilności Narodowej, które przetrwało przez większą cześć rządów junty gen. Suharto.

Kolejnym błędem w rozumowaniu jest, zdaniem Jonesa, pominięcie innych poza autorytaryzmem czynników, które mogły przyczynić się do ekonomicznych osiągnięć. Jeżeli to dyktatorzy czynia państwa bogatymi, to Afryka bylaby ekonomicznym kolosem - zauważa cynicznie „The Economist”. Równie dobrze wcześniejsza demokratyzacja mogłaby doprowadzić nie tylko do większych osiągnięć ekonomicznych (Tajwan, Singapur, Korea Południowa, Indonezja), lecz także zapewnić poszanowanie praw obywatelskich i politycznych, jak również praw ekonomicznych i społecznych.

Wielu amerykańskich polityków twierdzi, że nieskrępowany wzrost ekonomiczny implikuje poszanowanie praw człowieka, do którego poprzez domaganie się demokratyzacji dążyć będzie rosnąca grupa klasy średniej. Według klasycznej teorii „modernizacji” z końca lat 50. wzrost gospodarczy implikuje demokrację poprzez uruchomienie bezpośredniej zależności: urbanizacja $=>$ zmniejszenie analfabetyzmu $=>$ wzrost swobody wypowiedzi mediów $=>$ partycypacja społeczeństwa w procesach politycznych. O ile w przypadku Tajlandii, Tajwanu i Korei Południowej teoria ta się sprawdziła, to jednak poważnym wyzwaniem stała się dla niej konkurencyjna teoria deterministów kulturowych, marksistów, oraz teoria Lee Kuan Yew i in. singapurskich osobistości - Azjaci dbają o efektywność a nie o demokrację; porządek i rozwój są ważniejsze od wolności (podobny problem $\mathrm{z}$ uproszczoną korelacją w przypadku Indonezji, Malezji oraz Chin) ${ }^{62}$.

Mahathir bin Mohamad dowodząc odmienności pomiędzy zachodnim a azjatyckim (szczególnie dalekowschodnim) systemem wartości powołuje się na ba-

\footnotetext{
${ }^{61}$ Bilahari Kausikan, Asia `s Different Standard, "Foreign Policy", Fall 1993, s. 38.

${ }^{62}$ Sidney Jones, Asian Human Rights, Economic Growth and United States Policy, op.cit.
} 
dania Davida Hitchcocka, który przeprowadził wśród Amerykanów oraz mieszkańców Azji Wschodniej jednakową ankietę. Badacz ten poprosił o wskazanie sześciu kluczowych „wartości społecznych” oraz „osobistych”. Wyniki przedstawione w pracy Hitchcocka pt. „Wartości azjatyckie a Stany Zjednoczone; Jaki jest zakres konfliktu?” wykazały, iż najbardziej cenionymi „wartościami społecznymi” w Azji Wschodniej są (w tej kolejności): porządek społeczny i dobra organizacja, harmonia w społeczeństwie, zapewnienie odpowiedzialności funkcjonariuszy publicznych, swoboda samowyrażania się oraz poszanowanie władzy. W przypadku wartości amerykańskich na trzech pierwszych miejscach znalazły się: wolność wypowiedzi, prawa jednostki oraz wolności osobiste ${ }^{63}$.

\section{Konfucjanizm jako podstawa nowej etyki globalnej}

$\mathrm{Tu}$ Wenming przedstawia wizję zastąpienia starcia cywilizacji ich dialogiem, a w konsekwencji wypracowania nowej etyki dla społeczności globalnej. Etyka ta ma stanowić ponadnarodową syntezę najcenniejszych wartości zachodniego dziedzictwa renesansu i oświecenia oraz propozycji konfucjańskiej, które postrzega, jako „wzajemnie uzupełniające się”. Autor podkreśla, że „konfucjański humanizm może stanowić bogate źródło zasobów do rozwijania przez nas etyki ceniącej kulturową różnorodność, respektującą różnice i zachęcającą do pluralizm duchowych orientacji”. Zgodnie z powyższą teorią „konfucjański ideał jednostki (autentyczna osobowość, godność, mądrość) może być pełniej realizowany w społeczeństwie liberalnej demokracji niż w tradycyjnej dyktaturze imperialnej czy współczesnym reżimie autokratycznym”, zaś „,konfucjańska tradycja jest w stanie dostarczyć nam duchowych zasobów potrzebnych do rozwinięcia nowej wizji społeczeństwa, czerpiąc je z samego jądra oświeceniowych koncepcji. Konieczność wzniesienia się ponad oświeceniową mentalność jednak bez niszczenia lub porzucania jej oddania dla racjonalności, wolności, równości, praw ludzkich oraz niezależnego sądownictwa, wymaga wnikliwego rozważenia, jakiego rodzaju globalna etyka jest niezbędna dla przetrwania i rozwoju ludzkości” ${ }^{64}$.

Zdaniem Jana Rowińskiego propozycje i przemyślenia Tu Wenminga nabierają (zarówno w wymiarze światowym, jak i regionalnym) nowego, jakże aktualnego znaczenia ,jako paląca potrzeba zapełnienia próżni, która powstaje w warunkach tak głębokiego kryzysu ideologii, głoszonych wartości i pustki moralnej, będącej społecznym i moralnym kosztem transformacji w ChRL". Teoria profeso-

\footnotetext{
${ }^{63}$ Mahathir bin Mohamad, Rozważania o wartościach azjatyckich, „Azja-Pacyfik” 1999, t. 2, s. $161-162$.

${ }^{64}$ Tu Wenming, Rodzina, naród i świat.....s. 96-105.
} 
ra Tu może - przekonuje dalej J. Rowiński - „stanowić alternatywę dla wyraźnie utylitarnych, podporządkowanych potrzebom politycznym prób tworzenia specyficznej, azjatyckiej lub chińskiej tożsamości moralnej jako przeciwwagi dla wartości Zachodu i kwestionowania uniwersalnych wartości mających bezpośrednie odniesienie do praw człowieka" ${ }^{95}$.

${ }^{65}$ Jan Rowiński, Recenzja artykułu Tu Wenming, Rodzina, naród i świat....w: „Azja-Pacyfik” 2001, t. 4, s. 255.

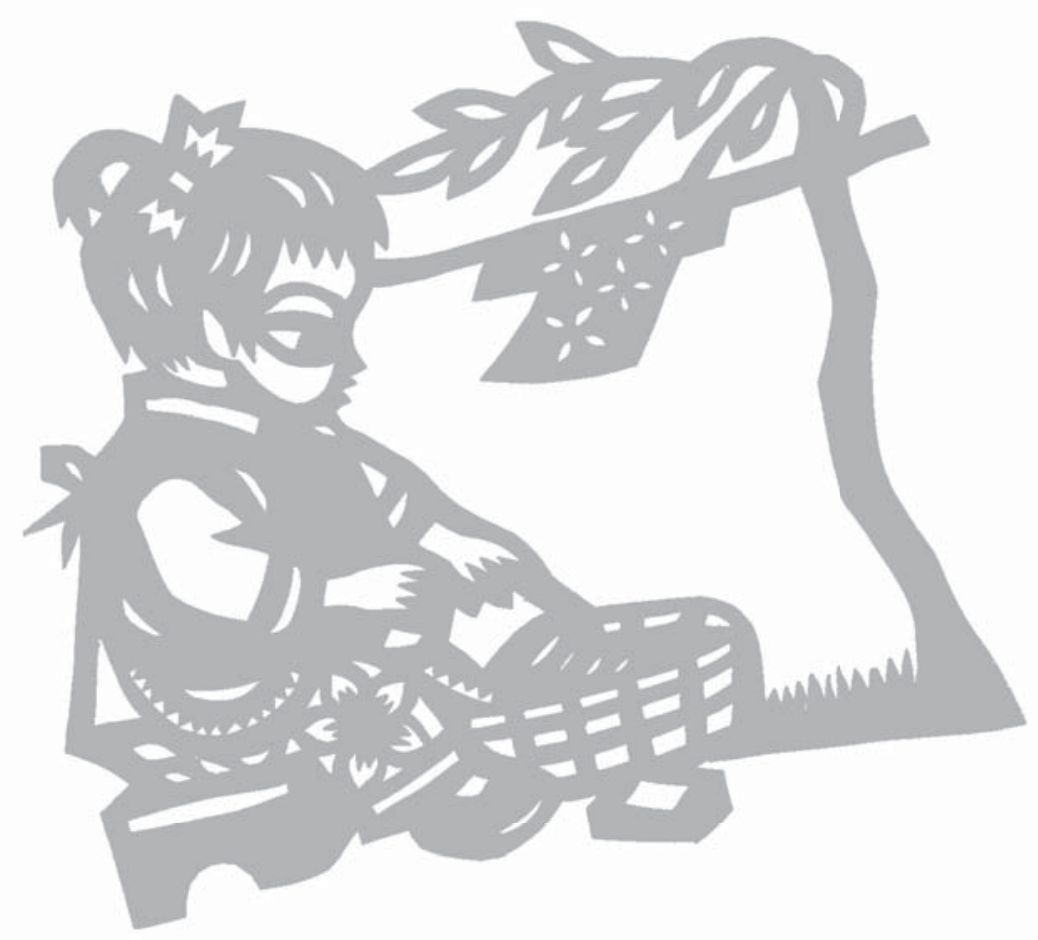

